ДОЦЕНКО С. І., д-р техн. наук, доцент, МОЙСЕСНКО В. І., Д-р техн. наук, професор,

СРМОЛЕНКО Л. П., аспірант кафедри спеціалізованих комп'ютерних систем

(Український державний університет залізничного транспорту)

\title{
Розвиток методології моделювання інформаційно-керуючих систем на залізничному транспорті
}

Методологія цілісного підходу, у якій діяльність представлена у формі структури задач, які вирішуються частинами організованого цілого, забезпечує вирішення основних проблем теорії діяльності, а отже, $\epsilon$ основною методологією, яку слід застосовувати при моделюванні підприємства. Методологія системного підходу є допоміжною до методології изілісного підходу $і$ забезпечує формування конкретних моделей, які входять до складу моделі підприємства як організованого ичілого.

Ключові слова: методологія, моделювання, система, організоване иүіле, цілісний підхід, організація.

\section{Вступ}

На залізничному транспорті проблеми, що розглядаються протягом багатьох років, вирішувалися адміністративно-командними методами. Це пояснюється тим, що до $60-\mathrm{x}$ років $\mathrm{XX}$ століття залізниця була військово-організованою структурою. Тому іiі організація і система керування копіювала військові підходи і 3 цієї причини систематичні дослідження 3 питань наукового обгрунтування принципів побудови та функціонування не проводились. Основи системного підходу до процесів залізничної галузі знайшли відображення у роботах В. М. Самсонкіна, В. I. Мойсеєнка та інших авторів. Але слід зазначити, що вони мають дещо звужений, функціональний характер, бо стосуються функційної безпечності.

У сформованому В. М. Самсонкіним системному підході до дослідження роботи залізничної транспортної системи вона розглядається як деяка саморегулююча субстанція 3 процесами гомеостазу та гомеорезу. Причому кінцевий результат діяльності досягається завдяки синергетичному ефекту.

Згідно 3 сучасними науковими уявленнями транспортну систему розглядають у вигляді конгломерату 3 трьома складовими: структурної, функціональної та якісної. Під складністю або рівнем організації системи розуміють кількість елементів, які беруть участь у досягненні кінцевого результату. Зусилля дослідників направлені на встановлення характеру взаємозв'язку складності й толерантності функиіональної системи.

Моделювання транспортної системи 3 застосуванням функціонального представлення забезпечує вирішення цілого ряду актуальних проблем залізничного транспорту. Серед них слід відзначити проблему технічної ефективності процесу використання засобів транспорту. Традиційно іï розглядають у межах теорії надійності шляхом визначення відповідних показників і співставлення їх iз нормативами.

Ці дані $є$ основою для формування відповідних інформаційно-керуючих систем. Застосування такого підходу до керування експлуатаційною роботою залізниці є проблематичним у зв'язку з труднощами, що виникають у разі спроби формалізації цих процесів, а також їх реінжинірингу.

Першою проблемою слід визнати потребу в модернізації зазначеного методологічного апарату шляхом розширення його функціональних можливостей і врахування особливостей транспортної галузі.

Не менш важливою $є$ проблема моделювання діяльності підприємств залізничного транспорту на основі структурного представлення. Справа в тому, що саме структурне представлення забезпечує формування організаційної структури підприємства, у межах якої формуються відповідні підрозділи, співробітники яких забезпечують реалізацію відповідних функцій.

Як правило, реформування підприємства залізничного транспорту полягає в реформуванні його організаційної структури, що вимушено призводить до необхідності узгодження зміненої організаційної структури зі змістом функцій, які реалізуються в організаційно-керуючій системі. Це призводить також до зміни інформаційних потоків і потоків даних, які формуються в системі. 3 цього випливає необхідність 
досліджувати зміну (реформування) інформаційного, функиіонального та організаційного представлень підприємства, які у стандарті ISO 19439:2006 Enterprise integration - Framework for enterprise modeling розглядаються як незалежні і застосовуються як основа для розроблення інтегрованої моделі підприємства.

За стандартом ISO 14258:1998 Industrial automation systems - Concepts and rules for enterprise models, існують різні методології, розроблені на основі загальної теорії систем, які мають відношення до різних аспектів представлення підприємства. Найчастіше застосовують такі три аспекти при формуванні відповідної системи: структурний, поведінковий та ієрархічний.

Визнання незалежності вказаних форм представлень 3 урахуванням наявності вказаних аспектів формування підприємства як системи породжує необхідність при реорганізації одного 3 представлень повністю реформувати й інші представлення. На жаль, на сьогодні невідомі однозначно визначені методи реформування моделей підприємств як систем для вказаних форм їх представлення з урахуванням визначених аспектів.

Проблема полягає також у тому, що зараз відсутнє однозначне визначення методології формування інтегрованої моделі підприємства, до складу якої одночасно включені взаємопов'язані та взаємообумовлені інформаційне та функціональне представлення.

Додатковою до цієї проблеми є проблема, яка полягає в тому, що інформаційно-керуюча система та підприємство як об'єкт керування розглядаються в різних теоріях. Відповідно, немає теорії яка б задовільно описувала цю модель 3 кібернетичної точки зору.

Проблемою $є$ також встановлення форми зв'язку поміж функціональним та організаційним представленнями підприємства як системи.

Проблема ускладнюється тим, що активного розвитку на цей час отримали інтелектуальні інформаційні технології, які $\epsilon$ основою для запровадження в галузі залізничного транспорту концепцій Індустрії 4.0 та Індустрії 5.0.

Отже, необхідно проаналізувати існуючий рівень досліджень моделей підприємства в таких формах представлень:

- функціональне представлення (теорія якеруван, теорія менеджменту);

- інформаційне представлення (теорія керування, кібернетика);

- організаційне представлення (теорія фірми, методологія).

Основою для всіх цих теорій $\epsilon$ методології системного та иілісного підходів. На жаль, на сьогодні недослідженою залишається проблема встановлення співвідношення вказаних методологій. Тому першою задачею є саме встановлення форми цього відношення.

\section{Аналіз досліджень}

Серед теорій, які досліджують, зміст поняття «організація» 3 точки зору як об'єкта, так і процесу перш за все слід відзначити тектологію (всезагальну організаційну науку) О. О. Богданова, яка вперше була опублікована в 1912 році [1]. Основним поняттям, яке застосовується в цій теорії, є поняття «організація». На жаль, пройшло вже більше ста років 3 моменту іiі публікації, однак основні положення цієї теорії до цього часу не знайшли широкого застосування.

Історично другою теорією, яка $\epsilon$ основою для дослідження та моделювання підприємства, є загальна теорія систем Л. фон Берталанфі, перша публікація 1928 рік [2], а основні результати були опубліковані в 50-ті роки минулого століття.

Паралельно 3 цією теорією отримала розвиток кібернетика, яка визначалася Н. Вінером як наука про керування та зв'язок у живих організмах і машинах [3]. Кібернетичний підхід до керування підприємством детально розроблявся С. Біром. У кібернетичному підході основою є методологія системного підходу.

Слід також відзначити, що разом 3 кібернетикою Н. Вінера отримала свого розвитку теорія функціональних систем як розділ фізіологічної кібернетики, автором якої є П. К. Анохін [4].

Сучасні успіхи розвитку кібернетики пов'язані 3 розробленням у першу чергу комп'ютерів. Даний напрям розвитку кібернетики має самостійну назву інформаційні технології керування. На основі наведеного в сучасній діяльності 3 курування підприємствами можна виділити такі форми їх реалізації:

- людина як суб'єкт керування;

- людина як об'єкт керування;

- автоматизовані за участю людини системи підтримки прийняття рішень (діалогові системи);

- автоматичні системи керування.

Для діяльності з керування, у якій суб'єктом діяльності є людина, існують декілька підходів до іï дослідження.

Теорію керування підприємством розробляли C. А. Олександров [5], В. М. Волкова [6], А. Ю. Заложнев [7], Д. О. Новиков [8], М. А. Коргін [9], А. П. Караваєв, В. М. Новосельцев, О. І. Орлов, Я. Стенлі [10], Г. Форестер [11].

Основоположником сучасної теорії менеджменту $є$ П. Ф. Друкер. Застосування теорії менеджменту в різних галузях діяльності розглянуто в роботах Є. Аксьонова, О. С. Нікітіна, О. О. Колобова та інших.

На початку XXI століття значного розвитку набула загальна теорія фірми. Дослідження в напрямі формування іiі фундаментальних положень виконували 
Я. Корнаі [12], Г. Б. Клейнер, R. Н. Coase, G. A. Calvo, S. Wellisz.

Психологічні аспекти діяльності людини як суб'єкта та об'єкта дій з керування досліджувалися перш за все в роботах Г. П. Щедровицького [13], який досліджував зміст поняття «діяльність» і першим звернув увагу на те, що його зміст має двоїстий характер: $з$ одного боку, діяльність розглядається як процес (або їх сукупність), а 3 іншого боку, як структура різнорідних елементів [29].

Для форми діяльності 3 керування, як автоматизованої системи за участю людини застосовуються інформаційні технології, розроблення яких виконували М. І. Мельцер [14], Г. С. Поспелов [15], Д. О. Новіков [16], А. Н. Бородулін [17].

Всі вказані підходи на підставі системної методології передбачають виділення у складі підприємства двох систем:

- керуючої системи;

- системи якою керують (об'єкт керування).

На основі цього підходу формуються всі можливі варіанти систем керування (менеджменту) підприємством та окремими аспектами його діяльності.

Загальноприйнятим у цих підходах також $є$ метод реалізації менеджменту через реалізацію циклу менеджменту, який вперше був описаний В. Шухартом [18] i відомий зараз як цикл Демінга - Шухарта. Реалізація циклу менеджменту у свою чергу передбачає реалізацію відповідних функцій [19].

У XXI столітті набула свого розвитку методологія як окрема наука про організацію діяльності [20, с. 20]: «методологія - це вчення про організацію діяльності».

«Тектологію» О. О. Богданова i «Методологію» О. М. Новікова слід вважати найбільш загальними методологіями.

Важливим напрямом теоретичних досліджень $\epsilon$ теорія моделювання, у якій досліджується проблема моделювання систем [21].

Необхідно також звернути увагу на те, що разом 3 класичною кібернетикою П. К. Анохіним була також запропонована теорія функціональних систем [4]. Подальший розвиток іiі виконали К. В. Судаков, К. О. Пупков, О. В. Чечкін та інші автори.

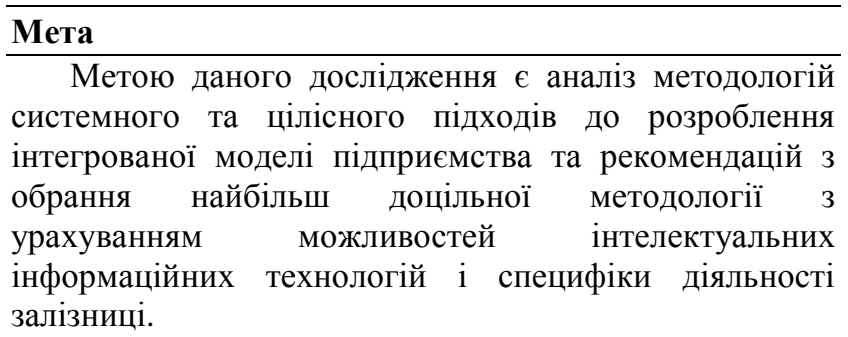

Аналіз основних положень методологій

моделювання підприсмства

На основі виконаного вище аналізу літературних джерел, у яких досліджено різні методології моделювання підприємства та його систем керування, сформовано таблицю. У ній наведено основні наукові підходи, які застосовуються для моделювання підприємства та його систем керування, а також визначено зміст методологій, які $\epsilon$ основою для визначених теорій. Для методологій визначено основні поняття, які є базовими для відповідних методологій.

Основними поняттями для досліджених методологій є саме поняття методологія, організація, система, фірма, організоване ціле.

Поняття система, фірма, організоване циіле характеризують підприємство як об'єкт у його існуванні. Найважливішими 3 цих трьох понять $\epsilon$ саме поняття система та організоване ичіле. Виникає задача дослідження співвідношення поміж цими поняттями.

Згідно з роботою [20] зміст поняття «методологія» визначається як «вчення про організацію діяльності». 3 іншого боку, О. О. Богданов зауважував [1, с. 29]: «Отже, задача тут наступна, щоб зорганізувати робочі сили та засоби виробництва у планомірно функціонуючу систему - це організація людей і речей у доцільну єдність».

3 цього визначення випливає, що зміст процесу організації полягає в «організації людей і речей у доцільну єдність».

Зміст поняття «організація», за роботою [20, с. 22], визначається так:

«1) внутрішня впорядкованість, узгодженість взаємодії більш-менш диференційованих і автономних частин цілого, обумовлена його будовою;

2) сукупність процесів або дій, що ведуть до утворення i вдосконалення взаємозв'язків між частинами цілого;

3) об'єднання людей, які спільно реалізують деяку програму або мету і діють на основі певних процедур і правил.

У нашому випадку ми використовуємо поняття «організація», в основному у першому і в другому значенні, тобто і як процес (друге значення), і як результат цього процесу (перше значення). Третє значення також використовується (але меншою мірою) - при описі колективної наукової діяльності, керування проектами в організаціях і т. д.».

Кінцевим результатом організаційного процесу є:

- у методології, за роботою [20], внутрішня впорядкованість, узгодженість взаємодії більш менш диференційованих і автономних частин цілого;

- у тектології, за роботою [1], організація доцільної єдності людей і речей. 
Основні положення методологій моделювання підприсмства

\begin{tabular}{|c|c|c|}
\hline Форма теорії & Застосовувана методологія, джерело & Основні поняття \\
\hline Тектологія & Системна методологія [1] & $\begin{array}{l}\text { Організація, система організоване } \\
\text { ціле (с. } 32) \text {, задача (c. } 24,30)\end{array}$ \\
\hline Загальна теорія систем & $\begin{array}{lll}\text { Системна } \quad \text { методологія } & {[2] .} \\
\text { Системний аналіз }[6,21] & \end{array}$ & Система, організоване ціле \\
\hline Кібернетика & Системна методологія [3] & $\begin{array}{l}\text { Кібернетична } \\
\text { самоорганізація, закон керування }\end{array}$ \\
\hline Самоорганізація систем & Системна методологія [11] & Система, самоорганізація \\
\hline Теорія функціональних систем & Системна методологія [4] & Система, організоване ціле \\
\hline \multirow[t]{4}{*}{ Інтелектуальні системи } & $\begin{array}{l}\text { Системна методологія } \\
\text { (К. В. Судаков) }\end{array}$ & $\begin{array}{l}\text { Функціональна } \\
\text { системоквант }\end{array}$ \\
\hline & $\begin{array}{ll}\text { Системна } & \text { методологія } \\
\text { (К. О. Пупков) } & \end{array}$ & Інтелектуальна система \\
\hline & Системна методологія (О.В.Чечкін) & Інтелектуальна система, радикал \\
\hline & Методологія цілісного підходу [24] & $\begin{array}{lll}\begin{array}{l}\text { Iнтелектуальна } \\
\text { організоване ціле }\end{array} & \text { система } & \text { як } \\
\end{array}$ \\
\hline Теорія організації & Системна методологія [5] & Організація \\
\hline Внутрішньо фірмове керування & Системна методологія [7] & Фірма, системна парадигма \\
\hline Організаційне керування & Системна методологія [8] & Організація, структура \\
\hline Активні системи & Системна методологія [9] & Активна система \\
\hline $\begin{array}{ll}\text { Системне } & \text { керування } \\
\text { організацією } & \end{array}$ & Системна методологія [10] & Організація \\
\hline Теорія фірми & Системна парадигма [12] & Фірма \\
\hline $\begin{array}{l}\text { Організаційно-управлінська } \\
\text { діяльність }\end{array}$ & Системна методологія [13] & Організація, діяльність \\
\hline Діалогові системи керування & Системна методологія [14] & Архітектура \\
\hline Програмно-цільове керування & Системна методологія [15] & Iерархія \\
\hline Інформаційне керування & Системна методологія [16] & Інформація \\
\hline Теорія менеджменту & Системна методологія [18] & Цикл керування \\
\hline $\begin{array}{l}\text { Функціональна } \\
\text { організації }\end{array}$ & Системна методологія [19] & Функція \\
\hline Методологія & Системна методологія [20] & $\begin{array}{l}\text { Організація, діяльність, система, } \\
\text { ціле }\end{array}$ \\
\hline Теорія моделювання систем & Системна методологія [21] & Модель \\
\hline
\end{tabular}

Отже, у цих методологіях результатом організаційного процесу, з одного боку, є «внутрішня впорядкованість, узгодженість взаємодії... диференційованих і автономних частин цілого», а 3 іншого - «доцільна єдність людей і речей», тобто в кінцевому рахунку «організоване ціле». Тобто в методології увага зосереджена на процесах «внутрішньої впорядкованості, узгодженості взаємодї», а в тектології на «організації доцільної $\epsilon \partial н о с т і »$.

Ключовими є поняття «узгодженість взаємодіі частин» і «єдність частин» цілого точніше поняття «взаємодія» та «єдність».

3 цього випливає, що, досліджуючи підприємство як об'єкт, необхідно визначити, яке 3 цих понять $є$ первинним у формуванні його моделі. Необхідно відповісти на питання, що необхідно дослідити в першу чергу при моделюванні підприємства: механізм забезпечення єдності частин цілого чи механізм реалізації їхньої взаємодії.

Якщо первинним визнається механізм реалізації взаємодії, тоді невизначеною $є$ модель цілого в «існуванні». Невідомо який принцип покладено в основу іiі формування?

Якщо ж первинним визнається принцип єдності частин цілого, тоді, знаючи, що поєднує частини організованого цілого, можна відповісти й на питання, як ця єдність реалізується в діяльності.

3 цього можливою $є$ пропозиція про визначення змісту розглянутих методологій:

- методологія системного підходу - це вчення про організацію діяльності систем;

- методологія цілісного підходу - це вчення про організацію цілого в «існуванні» та діяльності.

Перевагою другої методології $\epsilon$ те, що в ній визначається організація цілого в «існуванні». Ще 
Сократ дав таке визначення цілого [22]: «бо єдине $є$ тим, що складається 3 двох протилежностей, так що при розрізанні навпіл ці протилежності виявляються. Чи не це положення поставив, за словами еллінів, їхній великий і славний Геракліт в основу своєї філософії і пишався ним як новим відкриттям?»

3 цього визначення випливає, що до складу цілого достатньо включити щонайменше дві частини i визначити принцип їх поєднання. Принцип поєднання полягає в діалектичній протилежності станів цих частин. Розуміючи принцип формування цілого поєднанням його частин у ціле (діалектична єдність), можливим $€$ визначення змісту поняття «стан» для кожної з частин, а також визначення змісту механізму поєднання частин цілого в ціле.

Для системної методології проблемою $\epsilon$ визначення кількості їі елементів (частин), а також змісту механізму їх поєднання в систему. Ця проблема в теорії систем формулюється як проблема системоформуючого фактора. На сьогодні ця проблема в загальній теорії систем не вирішена [6].

Слід, однак, зауважити, що для інтелектуальних систем як організованих цілих, заснованих на теорії функціональних систем, ця проблема вирішена шляхом визначення проекту майбутнього результату в якості системоформуючого фактора [4].

3 іншого боку, у досліджених методологіях основною $є$ невизначеність форми відношення понять «система» та «організоване ціле».

Поняття «система» визнавалося первинним відносно цілого, як пропонував I. В. Блауберг [23]. Поняття «ціле» відносно системи характеризує іiі властивість «цілісність».

Однак у роботі [24]], на відміну від того, що пропонував I. В. Блауберг, первинним визначено поняття «ціле» і на основі цього сформовано правила організації існування та діяльності інтелектуальної системи як організованого цілого. У складі організованого цілого виділено дві системи, 3 яких перша система забезпечує формування цілі діяльності у формі проекту майбутнього результату, як це визначено в теорії функціональних систем [4]: «однак повернемося до природного розвитку подій при формуванні поведінкових актів на вищому рівні. Процес аферентного синтезу, як ми вже говорили, закінчується прийняттям рішення, що $\epsilon$ підсумком перебору можливих результатів, органічно пов'язаних у минулому 3 даною мотивацією. Таким шляхом здійснюється одне 3 найчудовіших явищ в активності мозку: формування на рівні нервової системи моделі всіх ознак i властивостей майбутнього корисного результату, у зв'язку з яким і заради якого розвивалися процеси аферентного синтезу. Це і $є$ метою».

Друга система забезпечує реалізацію встановленого проекту майбутнього результату. Діяльність цих двох систем поєднується механізмом забезпечення відповідності результатів діяльності вказаних систем.

При цьому діяльність кожної 3 систем запропоновано представляти у формі постановки та вирішення відповідних задач [24].

Отже, як у методології, так і тектології основною є методологія системного підходу, а методологія иілісного підходу визнається як допоміжна, яка розкриває властивість цілісності системи. 3 іншого боку отримала подальшого розвитку методологія цілісного підходу, у якій система визначається як частина відносно організованого цілого [24].

Виникає антиномія у формі протиріччя:

- основою дослідження «організації діяльності», або ж «доцільної єдності людей і речей», є методологія системного підходу;

- основою дослідження «організації діяльності», або ж «доцільної єдності людей і речей», є методологія иүілісного підходу.

Для розкриття цього протиріччя пропонується додатково розглянути зміст понять, які застосовуються при моделюванні підприємства.

\section{Визначення змісту поняття «модель»}

На перший погляд, відповідь на питання, що $\epsilon$ моделлю, дуже проста й зрозуміла: модель - це система, для якої визначено склад елементів і форми взаємодії поміж ними. Однак, за дослідженням відношення понять «модель» i «система», яке виконано в роботі [21], існують певні умови, при яких система може бути представлена як модель. При цьому модель визначається так [21, с. 26]: «але при описі реальних об'єктів доводиться розрізняти модель як множину елементів певної природи, пов'язаних властивими моделі відносинами, i структуру як абстрактну категорію, з точки зору якої неважливо, 3 чого складається несуча множина моделі та якою $є$ реальна природа відносин на цій моделі».

Стосовно визначення змісту відношення понять «модель» і «система» в роботі [21] відмічається: «отже, система сама по собі не модель і навіть не множина, але може бути представлена як модель. Базовою множиною цієї моделі є безліч компонентів, що виникають у даному членуванні. Ця множина не будується $з$ заздалегідь заданих елементів, а, навпаки, елементи ऑï (компоненти системи) формуються в процесі опису (дослідження) системи. Зате після того як ці елементи виділені, їх повний склад чітко визначається системою. Кожне членування системи утворює закриту сукупність, а не відкритий клас. Ясно, що система може мати багато уявлень: може бути представлена багатьма способами».

3 наведеного випливає, що модель - це «множина елементів певної природи, пов'язаних властивими моделі відносинами», для якої додатково вводиться поняття «структура». Якщо для системи визначена 
множина елементів певної природи, а також властиві моделі відносини і визначена структура цих відносин поміж елементами таку систему можна вважати моделлю.

3 іншого боку, таке визначення моделі як системи породжує багатоваріантність ії представлення, вона «може бути представлена багатьма способами». Виникає питання, які це способи? У другій частині статті планується дослідження цього питання.

Стосовно організованого цілого також виникає питання, чи можна вважати організоване ціле, яке розглянуто вище, як модель? Звичайно, адже для нього визначено склад (частин) елементів- їх лише дві, а також принцип поєднання - діалектична єдність. Цього достатньо для формування моделі організованого цілого в «існуванні».

Однак залишається проблема моделювання діяльності цього організованого цілого. Проблема ускладнюється тим, що зміст самого поняття «діяльність» має двоїстий характер.

\section{Визначення змісту поняття «діяльність»}

Розглянемо більш детально зміст категорії «діяльність» на основі результатів, отриманих у теорії діяльності. Е. Г. Юдин дає таке визначення поняття «діяльність» [25, с. 246]: «щоб був зрозумілий предмет обговорення, приймемо як вихідне таке визначення діяльності: діяльність є специфічно людською формою активного ставлення до навколишнього світу, зміст якої складає доцільна зміна і перетворення цього світу на основі освоєння i розвитку існуючих форм культури».

Далі Е. Г. Юдин вводить поняття «структура діяльності» [25, с. 247-248]: «загальна структура діяльності включає в себе мету, засіб, результат і сам процес діяльності. Доцільний характер діяльності призводить до того, що однією 3 найголовніших іiі умов i підстав $\epsilon$ свідомість, що розуміється в найширшому сенсі не тільки як сукупність найрізноманітніших форм свідомості, але і як безліч його внутрішніх регулятивів (потреб, мотивів, установок, цінностей і т. д.). Свідомість відіграє в діяльності двояку роль: з одного боку, вона виступає як іiї внутрішня компонента, засіб контролю за ходом діяльності, з іншого боку, сфера свідомості виступає як зовнішня відносно діяльності, як джерело формування уявлень про іiі цілі, сенс і оцінку. 3 особистісної точки зору діяльність являє собою єдність інтеріоризації (освоєння людиною сукупності умов іiі життя i діяльності та формування на цій основі особистісних характеристик і здібностей) i екстеріоризації (втілення здібностей і задумів людини в продуктах іiі діяльності)...».

3 наведеного випливає, що головною передумовою організації діяльності організованих цілих $є$ «свідомість».
Внутрішня функція свідомості полягає в «контролі за ходом діяльності», а зовнішня полягає у «формуванні уявлень про іiі цілі, сенс і оцінку діяльності».

Відмічаючи роль категорії «діяльність», Е. Г. Юдин підкреслює [25, с. 249-250]: «місце і роль поняття діяльності визначаються насамперед тим, що воно належить до розряду універсальних, граничних абстракцій. Такі абстракції втілюють у собі якийсь «наскрізний» зміст: вони дають змістовний вираз одночасно і найелементарнішим актам буття, і його глибинним підставам, проникнення в які робить розумом пізнавану справжню цілісність світу...

Стосовно поняття діяльності (тобто враховуючи вживання цього поняття тільки в контексті наукового мислення) можна вказати як мінімум п'ять його різних функцій:

1) діяльність як пояснювальний принцип - поняття 3 філософсько-методологічним змістом виражають універсальну підставу (або в більш обережному формулюванні універсальну характеристику) людського світу;

2) діяльність як предмет об'єктивного наукового вивчення;

3) діяльність як предмет керування - те, що підлягає організації в систему функціонування і (або) розвитку на основі сукупності фіксованих принципів;

4) діяльність як предмет проектування, тобто виявлення способів і умов оптимальної реалізації певних (переважно нових) видів діяльності;

5) діяльність як цінність, тобто розгляд місця, яке займає діяльність у різних системах культури».

Ця теза Е.Г. Юдина підкреслює потенціальну значущість категорії «діяльність» для методології системного підходу. Слід відзначити, що лише в концепції рефлексивного керування О. В. Авілова категорія «діяльність» отримала своє практичне застосування в розкритті змісту діяльності з керування [26].

Щодо діяльності як предмета об'єктивного наукового вивчення в методології системного підходу, який «членується і відтворюється в теоретичній картині певної наукової дисципліни», таким предметом є категорія «процес».

Загальновизнаним у методології системного підходу є визначення діяльності як процесу. 3 іншого боку, існують дослідження в галузі теорії діяльності, результати яких піддають сумніву наведене представлення категорії «діяльність». Результати таких досліджень наведені в роботі Г. П. Щедровицького [27].

Загальні проблеми цієї теорії сформульовано ним у такій формі: «по суті справи, емпіричні дисципліни, що вивчають діяльність, прийшли зараз до такого положення, коли вже накопичено досить багато емпіричних співвідношень, що описують окремі групи 
фактів. Але не вистачає одного і найголовнішого виділення діяльності не в якості такого об'єкта, яким вона виступає в різних своїх проявах, а в якості ідеального предмета вивчення... .

Тому постає питання: якщо діяльність - це особливий об'єкт, не схожий на інші і виділений вже давно, і якщо велика кількість дослідників займаються аналізом діяльності, то чому досі не отримано істотних результатів і 3 чим тут перш за все стикається дослідження?»

На це питання він дає таку відповідь [27]: «ми не тільки не знаємо, що таке діяльність, але також не знаємо, як це дізнатися... Філософською мовою це означає, що в нас нема відповідних категорій. 3 подібною ситуацією людство стикається аж ніяк не вперше. Але останнім часом саме через розрив між соціальними, гуманітарними науками i технічними науками цей момент, як правило, не береться до уваги. А саме, щоб вивчати діяльність, ми повинні не тільки виділити іiі як об'єкт, але і якось 3 ним діяти, ми повинні ще додатково виробити систему засобів для його аналізу.

Наша дослідницька робота повинна давати два різні продукти: з одного боку, повинні вироблятися знання про діяльність, а з іншого боку, і це по суті справи є умовою і передумовою всієї роботи, повинні вироблятися певні засоби і методи. У міру того, наскільки ми зуміємо розробити ці нові засоби i методи, ми отримаємо якісь знання про діяльність».

Таким чином, Г. П. Щедровицький ставить дві задачі:

- визначення критерію для категорії «діяльність»;

- визначення (розроблення) методу дослідження (аналізу та синтезу) діяльності як такої.

Аналіз існуючих методів дослідження діяльності як об'єкта пізнання дозволив Г. П. Щедровицькому виявити такі проблеми [27]: «перший захід, 3 якого починають, - це твердження, що діяльність $\epsilon$ процесом. I потім їі починають вивчати як процес. Нехай є певні емпіричні прояви, скажімо, дії однієї або іншої людини або робота деякої установи. Аналізувати таку роботу як процес - означає розкласти їі на деяку послідовність, «шматочків», у часі, потім задати її ж як ціле і нарешті встановити процедури, які дозволяють від цих «шматочків», що розглядаються як одиниці, переходити до цілого, що охоплює їх.

Отже, коли говорять, що діяльність є процесом, то це означає віру в можливість виділити такі «шматочки» - маленькі процеси або операції, які, з'єднуючись один з одним в лінійну послідовність або розгалужені ланцюги, дадуть нам у результаті діяльність.

Перше, з чим стикається тут дослідник, - це те, що нікому не вдалося виділити таких «шматочків», або операцій. Тут потрібно назвати дві основні причини невдач.
Перша пов'язана 3 розходженням процесу i результату діяльності...

Друге ускладнення. Незрозуміло, хто і що є носієм діяльності... Коротше кажучи, кожного разу ми встаємо тут перед двома питаннями: 1) до якого матеріалу потрібно прив'язувати те, що ми називаємо людською діяльністю, і 2) якими одиницями ми можемо при цьому обмежуватися?»

Г. П. Щедровицький так відповідає на ці запитання [27]: «отже, основна мета у виділенні предмета вивчення - це завдання такої обмеженої області, всередині якої ми могли б знайти деякі закони та закономірності...

У результаті ми підходимо до принципової тези: якщо діяльність не є процесом і діяльність не є річчю, то що ж це таке? Відповідь: діяльність є структурою...

Потрібно лише додати, що в даному випадку розуміється структура, що включає неоднорідні елементи: кожен 3 цих елементів знаходиться ще, крім того, у процесі свого власного руху, розвитку та функціонування. Це - дуже важливе зауваження...

Отже, коли я кажу, що щось $є$ найпростішою одиницею, я стверджую, що тільки такий мінімальний набір може розглядатися як деяка цілісність, що підкоряється певному закону...

Умовою побудови предмета вивчення діяльності $\epsilon$, 3 моєї точки зору, принциповий поворот у категоріальному розумінні діяльності».

3 наведеного Г. П. Щедровицьким визначення категорії «діяльність» може бути сформована антиномія - «діяльність як процес» - «діяльність як структура організаційних задач» склад яких у першому наближенні визначено нами на початку даного пункту.

Ця антиномія є аналогом антиномії I. В. Блауберга про свідому та несвідому діяльність [23]: «оскільки ідея цілого може бути показана лише шляхом свого розкриття в частинах, a, з іншого боку, окремі частини можливі лише завдяки ідеї цілого, то ясно, що тут $є$ протиріччя, яке переборне лише для генія, тобто шляхом раптового збігу свідомої і несвідомої діяльності».

3 цього виникає можливість висловити припущення про можливість представлення поєднання (поки що невідомо як саме) «свідомої» та «несвідомої» діяльностей в одиницю діяльності.

За Е.Г. Юдиним, структура етапів реалізації «свідомої діяльності» в загальній формі включає такі форми діяльності:

- формування цілі діяльності;

- контроль за ходом діяльності 3 досягнення встановленої цілі;

- оцінювання досягнутого результату діяльності.

У термінології О.О. Богданова ці форми діяльності $\epsilon$ нічим іншим, як організаційними задачами, тобто вирішуються такі організаційні задачі: - задача формування цілі діяльності; 
- задача контролю за ходом діяльності 3 досягнення встановленої цілі;

- задача оцінювання досягнутого результату діяльності.

За Г.П. Щедровицьким, у теорії діяльності введено такі категорії:

- діяльність - це структура, яка включає неоднорідні елементи;

- одиниця діяльності як деяка цілісність, що підпорядкована певному закону.

А також поставлено такі запитання:

- чим є людська діяльність?

- що є «одиницею» цієї діяльності, ії цілісністю?

- що собою являє структура одиниці діяльності?

- що собою являють неоднорідні елементи цієї структури?

- якими методами необхідно досліджувати діяльність?

Категорія «одиниця діяльності» є тією категорією, розкриття змісту якої забезпечить встановлення нових закономірностей діяльності як окремої людини, так і підприємства, а також інформаційно-керуючих систем, які реалізують відповідні функції у складі підприємства.

Відповіді на ці запитання отримано в роботі [24] шляхом дослідження основних положень теорії функціональних систем.

\footnotetext{
Висновки

3 наведеного випливає, що саме методологія цілісного підходу, у якій діяльність представлена у формі структури задач, які вирішуються частинами організованого цілого, забезпечує вирішення основних проблем теорії діяльності, а отже, $\epsilon$ основною методологією, яку слід застосовувати при моделюванні підприємства. Методологія системного підходу $\epsilon$ допоміжною до методології цілісного підходу і забезпечує формування конкретних моделей систем 3 урахуванням визначених в ISO 14258-98 аспектів моделювання для систем, які входять до складу моделі підприємства як організованого цілого.

Проблема встановлення співвідношення для понять «система» та «організоване ціле» вирішена шляхом встановлення співвідношення поміж результатами діяльності організованого цілого та системи, діяльність якої присвячена вирішенню певної задачі.

Важливою проблемою при цьому $\epsilon$ проблема формування механізму забезпечення відповідності результатів задач вирішуваних частинами організованого цілого (системами). При цьому на перший план виходить задача формування цілі діяльності підприємства.

Інтегрована модель підприємства може бути представлена як організоване ціле, для якого додатково необхідно визначити структури для кожної
}

3 підсистем і структуру для механізму забезпечення відповідності результатів рішення задач.

\section{Список використаних джерел}

1. Богданов А. А. Тектология: Всеобщая организационная наука / Международный институт Александра Богданова. Редколлегия В. В. Попков (отв. ред.) и др.; составление, предисловие и комментарии Г.Д. Гловери. Послесловие В. В. Попкова. Москва : ФИНАНСЫ, 2003. 496 с.

2. Bertalanffy L. von. General System Theory A Critical Review. General Systems. Vol. VII, 1962. P. $1-20$.

3. Винер Н. Кибернетика или Управление и связь в животном и машине: пер. с англ. И. В. Соловьева, Г. Н. Поварова; под ред. Г. Н. Поварова. - Изд. 2-е. Москва : Наука; Главная редакция изданий для зарубежных стран, 1983. 344 с.

4. Анохин П. К. Избранные труды. Философские аспекты теории функциональной системы / отв. ред. Ф. В. Константинов, Б. Ф. Ломов, В. Б. Швырков. Москва : Изд-во Наука. 1978. 400 с. C. 122.

5. Александров Е. А., Боголепов В. П. О некоторых организационных критериях качества функционирования систем (К вопросу о создании математического аппарата теории организации). Организация и управление (Вопросы теории и практики). Москва, 1968. 222 с.

6. Теория систем и методы системного анализа в управлении и связи / В. Н. Волкова, В. А. Воронков, А. А. Денисов и др. Москва : Радио и связь, 1983. 248 с.

7. Заложнев А. Ю. Модели и методы внутрифирменного управления. Москва : СтормМедиа, 2004. 320 с.

8. Новиков Д. А. Иващенко А. А., Модели и методы организационного управления инновационным развитием фирмы. Москва : ЛЕНАНД, 2006. 332 с.

9. Коргин Н. А. Неманипулируемые механизмы обмена в активных системах. Москва : ИПУ РАН, 2003. $126 \mathrm{c}$.

10. Стэнли Я. Системное управление организацией. Москва : Советское радио, 1972, 456 с.

11. Ферстер Г. О самоорганизующихся системах и их окружении. Самоорганизующиеся системы. 1964. C. $160-165$.

12. Корнаи Я. Системная парадигма. Bonpocbl экономики. 2002. № 4. С. 4-22.

13. Щедровицкий Г. П. Методология и философия организационно-управленческой деятельности: основные понятия и принципы. Москва: Наука, 2003. T. 5. 288 c.

14. Мельцер М. И. Диалоговое управление производством (модели и алгоритмы). - Москва : Финансы и статистика, 1983. 240 с. 
15. Поспелов, Г. С. Программно-целевое планирование и управление. (Введение). Москва : Сов. радио, 1976. $440 \mathrm{c}$.

16. Новиков Д. А., Чхартишвили А. Г. Прикладные модели информационного управления. Москва : ИПУ РАН, 2004. 124 с.

17. Бородулин А. Н., Заложнев А. Ю., Шуремов Е. Л. Внутрифирменное управление, учет и информационные технологии. Москва : ПМСОФТ, 2006. $340 \mathrm{c}$.

18. Shewhart W. Economic control of Quality of Manufactured Product. New York: D.Van Nostrand Co., 1931. P. 53-54.

19. Марков Ю. Функциональный подход в современном научном познании / отв. ред. А. Н. Кочергин, М. В. Глазырин ; $\mathrm{AH} \mathrm{CCCP,}$ Сибирское отд-ние, Ин-т истории, филологии и философии. Новосибирск : Наука, 1982. 255 с.

20. Новиков А. М., Новиков Д. А. Методология. Москва : СИНТЕГ, 2007. 668 с.

21. Шрейдер, Ю. А., Шаров А. А. Системы и модели. Мосвка : Радио и связь, 1982. 152 с.

22. Конспект книги Лассаля «Философия Гераклита Темного из Эфеса» 1915 или 1916 г. Берн / В. И. Ленин. Философские тетради; под ред. В. В. Адоратского и В. Г. Сорина. Изд-во ЦК ВКП (б) 1934 г. 475 с. С. $309-322$.

23. Блауберг И. В. Проблема целостности и системный поход. Москва : Эдиториал УРСС, 1997.448 с.

24. Доценко C. I. Теоретичні основи створення інтелектуальних систем комп'ютерної підтримки рішень при управлінні енергозбереженням організацій : дис. ... д-ра техн. наук : 05.13.06 / Харківський національний технічний університет сільського господарства імені Петра Василенка. Харків, 2017. 369 с.

25. Юдин Э. Г. Методология науки. Системность. Деятельность. Москва : Эдиториал УРСС, 1997. $445 \mathrm{c}$.

26. Авилов А. В. Рефлексивное управление: методологические основания. Горький : Изд-во ГУУ, 2003. 202 с.

27. Щедровицкий Г. П. Теория деятельности и ее проблемы 1966. Философия. Наука. Методология Philosophy science methodology. Москва : Издательство: Школа Культурной Политики, 1997. URL : http://www.fondgp.ru/gp/biblio/rus/98

\begin{tabular}{lll} 
Доценко С. И., Моисеенко В. И., Ермоленко Л. П. \\
Развитие & методологии & \multicolumn{2}{c}{ моделирования } \\
информационно-управляющих & систем н на \\
железнодорожном транспорте. &
\end{tabular}

Аннотация. Методология целостного подхода, в которой деятельность представлена в форме структуры задач, которые решаются частями организованного целого, обеспечивает решение основных проблем теории деятельности, a, следовательно, является основной методологией, которую следует применять при моделировании предприятия. Методология системного подхода является вспомогательной методологией целостного подхода и обеспечивает формирование конкретных моделей, входящих в состав модели предприятия как организованного целого.

Ключевые слова: методология, моделирование, система, организованное целое, целостный подход, организация.

Dotsenko S. I., Moiseenko V. I., Ermolenko L. P. Development of methodology of modeling of information and control systems on railway transport. Abstract. In railway transport, the problems that have been considered for many years were solved by administrative - command methods. This is due to the fact that until the 60 s of the 20th century, the railway was a military - organized structure. Therefore, its organization and management system copied military approaches and, for this reason, systematic studies on the scientific substantiation of the principles of construction and operation were not carried out. The foundations of a systematic approach to the processes of the railway industry are reflected in the work of prof. V.M. Samsonkina, prof. V.I. Moiseenka and other authors. It should be noted that they have a somewhat narrowed, functional nature, as they relate to functional safety. In the systematic approach to the operation of the railway system, formed by Professor V.M. Samsonkin, it is considered as a kind of self-regulating substance with processes of homeostasis and homeoresis. The study proved that the methodology of a holistic approach, in which the activity is presented in the form of a structure of tasks that are solved by parts of an organized whole, provides a solution to the main problems of the theory of activity, and therefore is the main methodology that should be applied when modeling the enterprise. The methodology of the system approach is an auxiliary methodology in relation to the methodology of a holistic approach and provides the formation of specific models that are part of the enterprise model as an organized whole. The concept of "system" and "organized whole" are interconnected as a "part" - "whole", that is, the system is part of the whole. It is proposed that each part of the organized whole be considered as a system whose activity is dedicated to solving a specific problem. An important problem is the problem of the formation of a mechanism to ensure compliance with the results solved by these parts (systems) of tasks. In the traditional approach to enterprise modeling, the composition and content of the processes that are implemented by this mechanism correspond to the functions that are implemented by the information 
management system. However, from the point of view of classical cybernetics, the task of ensuring the correspondence of the obtained result of activity to its project is considered as a problem of self-organization of the enterprise. At the same time, the task of forming the goal of the enterprise's activity comes to the fore.

Keywords: methodology, modeling, organized whole system, holistic approach, organization.

Надійшла 18.05.2020 p.

Доценко Серій Ілліч, д-р техн. наук, доцент, доцент кафедри спеціалізованих комп'ютерних систем, Украӥнський державний університет залізничного транспорту, Харків, Украӥна. E-mail: sirius_3k3@ukr.net, $\quad$ http://orcid.org/0000-0003-30214192.

Мойсеєнко Валентин Іванович, д-р техн. наук, професор, завідувач кафедри спеціалізованих компютерних систем, Український державний університет залізничного транспорту, Харків, Україна. E-mail: mvi53@ukr.net http://orcid.org/00000003-1377-8703.

Срмоленко Людмила Павлівна, аспірант кафедри спеціалізованих комп'ютерних систем, Украӥнський державний університет залізничного транспорту, Харків, Україна. E-mail: $\quad$ ermolenkolp1@gmail.com http://orcid.org/0000-0003-0732-3999.

Sergiy Dotsenko, Doctor of Technical Sciences, Associate Professor at the Department of specialized computer systems, Ukrainian State University of Railway Transport, Kharkiv, Ukraine. E-mail: sirius_3k3@ukr.net, http://orcid.org/0000-0003-3021-4192.

Valentin Moiseenko, Doctor of Technical Sciences, Professor, head of Department of specialized computer systems of Ukrainian State University of Railway Transport, Kharkiv, Ukraine. E-mail: mvi53@ukr.net http://orcid.org/0000-0003-1377-8703.

Liudmyla Yermolenko, graduate student, Department of specialized computer systems of Ukrainian State University of Railway Transport, Kharkiv, Ukraine. E-mail: ermolenkolp1@gmail.com http://orcid.org/00000003-0732-3999. 